University of Nebraska - Lincoln

DigitalCommons@University of Nebraska - Lincoln

Faculty Papers and Publications in Animal

Science

Animal Science Department

January 1981

\title{
COMPARISON OF THREE-BREED AND BACKCROSS SWINE FOR LITTER PRODUCTIVITY AND POSTWEANING PERFORMANCE
}

\author{
E. R. Wilson \\ Oklahoma State University, Stillwater \\ R. K. Johnson \\ University of Nebraska-Lincoln, rjohnson5@unl.edu
}

Follow this and additional works at: https://digitalcommons.unl.edu/animalscifacpub

Part of the Animal Sciences Commons

Wilson, E. R. and Johnson, R. K., "COMPARISON OF THREE-BREED AND BACKCROSS SWINE FOR LITTER PRODUCTIVITY AND POSTWEANING PERFORMANCE " (1981). Faculty Papers and Publications in Animal Science. 19.

https://digitalcommons.unl.edu/animalscifacpub/19

This Article is brought to you for free and open access by the Animal Science Department at DigitalCommons@University of Nebraska - Lincoln. It has been accepted for inclusion in Faculty Papers and Publications in Animal Science by an authorized administrator of DigitalCommons@University of Nebraska - Lincoln. 


\title{
COMPARISON OF THREE-BREED AND BACKCROSS SWINE FOR LITTER PRODUCTIVITY AND POSTWEANING PERFORMANCE ${ }^{1}$
}

\author{
E. R. Wilson ${ }^{2}$ and R. K. Johnson ${ }^{3}$ \\ Oklaboma State University, Stillwater 74074
}

\begin{abstract}
Summary
Duroc, Hampshire and Yorkshire boars were mated with crossbred gilts of Duroc-Hampshire, Duroc-Yorkshire and Hampshire-Yorkshire breeding to produce 133 three-breed and 259 backcross litters that were farrowed during four seasons beginning in the fall of 1975. Threebreed cross litters were $.31 \pm .27, .57 \pm .24$ and $.50 \pm .24$ pigs larger than backcross litters at birth, 21 and 42 days, respectively, and $.6 \pm$ $.34,2.3 \pm 1.2$ and $5.4 \pm 2.4 \mathrm{~kg}$ heavier at these ages. The differences in average pig weight and survival percentage were small. Three-breed cross litters gained faster $(.024 \pm .007 \mathrm{~kg} /$ day $)$ and were younger $(-4.7 \pm 1.5$ days) at 100 kilograms. Three-breed cross pigs were about $3 \%$ more efficient than backcross pigs. The differences in average backfat probe and average daily feed intake were small and not significant. Breed of sire contrasts for litter traits were small and not significant. However, significant differences between sire breeds existed for postweaning performance. Also, few differences between crossbred dam groups were significant for litter size or litter weight, but significant differences in postweaning performance existed between progeny of crossbred dam groups. In general, pigs with Duroc breeding had the fastest growth rate and those with Hampshire breeding were the leanest.
\end{abstract}

(Key Words: Swine, Crossbreeding Systems, Litter Productivity, Post-weaning Performance.)

\section{Introduction}

Reports on specific two- and three-breed

\footnotetext{
${ }^{1}$ Journal Article 3616 of the Agr. Exp.Sta, Oklahoma State Univ., Stillwater. Research conducted by the Dept. of Anim. Sci. (Project 1620) in cooperation with the USDA, ARS, Southern Region.

${ }^{2}$ KLEEN LEEN, INC., 2720 First Ave., NE, Cedar Rapids, IA 52402. 68503

${ }^{3}$ Dept of Anim. Sci., Univ. of Nebraska, Lincoln,
} 18

crosses of swine (Smith and McLaren, 1967; Fahmy and Bernard, 1971; Fahmy et al., 1971; Nelson and Robison, 1976; Schneider, 1976; Sellier, 1976; Young et al., 1976a,b; Johnson et al., 1978.) have clearly shown the existence of individual and maternal heterosis for important swine production traits. Since maternal heterosis has been shown to increase significantly the number of pigs and litter weight at 42 days (Johnson et al., 1978), a crossbred dam should be used in commercial swine production. However, several considerations must be made in the selection of breeds and breed combinations for mating systems. As an example, three-breed terminal crosses maintain $100 \%$ individual and maternal heterosis but are more complex to manage than two-breed systems, which have less than maximum heterosis. Another example is a rotation cross, which allows a producer to raise replacement females but maintains less than maximum heterosis.

There is a lack of experimental results for evaluating different mating schemes. Experimental results that verify the relationship between heterosis and degree of heterozygosity are also lacking.

The purpose of this experiment was to evaluate three-breed cross and backcross pigs from dams of Duroc-Hampshire,Duroc-Y orkshire and Hampshire-Yorkshire breeding for litter and growth traits. Specific objectives were to compare the estimate of one-half individual pig heterosis from this study with earlier estimates of heterosis, and to compare the performance of the three types of crossbred dams and sire breeds for litter traits and postweaning performance.

\section{Materials and Methods}

Backcross and three-breed cross litters of Duroc, Hampshire and Yorkshire breeding were farrowed and raised at the Southwest Livestock and Forage Research Station, El Reno, Okla- 
homa. Farrowings occurred during four seasons, from the fall of 1975 to the spring 1977.

Purebred boars and crossbred females were produced at the OSU swine farm at Stillwater from the purebred Duroc, Hampshire and Yorkshire herds that had been established in 1969 (Johnson et al., 1973). All females farrowing were gilts.

An 8-week breeding season was used each season, with the fall breeding beginning December 1 and the spring breeding beginning June 1. Farrowings took place in a central farrowing house with crates and slotted wood floors. At approximately 1 week of age, the litters were moved to a nursery with individual pens and solid concrete floors. All boars were castrated at 21 days of age and creep feed was offered at this time. Litters were weaned at $\mathbf{4 2}$ days and about 2 weeks later were moved to the finishing facility. Pigs were group fed in concrete pens, with 10 to 18 animals per pen. They were allotted to pens by breed group, with barrows and gilts mixed in pens, and started on test at approximately 9 weeks of age. Diets were $16 \%$ protein to about $50 \mathrm{~kg}$ and $14 \%$ protein from 50 to $100 \mathrm{~kg}$, with either wheat or sorghum as the grain base. Pigs were weighed off-test weekly as they approached $100 \mathrm{~kg}$, at which time they were probed for backfat.

Gilts were monitored during the breeding period and classified into one of three categories: (1) not detected in estrus. (2) detected in estrus and mated but did not become pregnant or (3) pregnant. The records for five gilts that forrowed were deleted from analyses of
21- and 42-day litter traits because one died and four lost their litters between birth and 21 days.

The experimental design and the number of boars, sows and pigs per breed or breed cross are presented in table 1 . Data were collected on the reproductive success rate of the gilts, litter size, litter weight and individual pig weight at birth and 21 and 42 days. Differences in conception rates among crossbred female breed groups were compared by chi-square tests (Snedecor and Cochran, 1967). Growth rate, days to $100 \mathrm{~kg}$, average backfat probe and pen feed efficiency were evaluated postweaning. All fully formed pigs (alive or dead) were included in litter size at birth.

Statistical analyses of litter productivity and postweaning performance were done on litter means. Average daily gain, days to $100 \mathrm{~kg}$ and average probe backfat measurements for gilts were adjusted to a barrow basis by the addition to gilt records of the mean difference between barrow and gilt data. Postweaning performance was analyzed in this manner because these estimates gave unbiased estimates of population parameters and produced an input matrix that could be inverted by existing computer facilities. This technique was also used by Young et al. (1976b) and Johnson et al. (1978).

The statistical model was:

$$
\begin{gathered}
y_{i j k l m}=u+S_{i}+B_{j}+(S B)_{i j}+R_{k(i j)}+D_{1}+ \\
(S D)_{i l}+(B D)_{i l}+(S B D)_{i j l}+e_{m(i j k l)}
\end{gathered}
$$

TABLE 1. EXPERIMENTAL DESIGN AND DISTRIBUTION OF

\begin{tabular}{|c|c|c|c|c|c|c|}
\hline $\begin{array}{l}\text { Breed of } \\
\text { sire' }\end{array}$ & $\begin{array}{l}\text { No. of } \\
\text { sires }\end{array}$ & $\begin{array}{l}\text { Breed of } \\
\text { gilt } t^{\mathrm{a}}\end{array}$ & $\begin{array}{l}\text { No. of } \\
\text { litters at } \\
\text { birth }\end{array}$ & $\begin{array}{l}\text { No. of } \\
\text { litters } 21 \text { and } \\
42 \text { days }\end{array}$ & $\begin{array}{l}\text { No. of } \\
\text { pigs in } \\
\text { feedlot }\end{array}$ & $\begin{array}{l}\text { No. of } \\
\text { pens for feed } \\
\text { efficiency }\end{array}$ \\
\hline Duroc & 24 & $\begin{array}{l}\text { DH } \\
\text { DY } \\
\text { HY }\end{array}$ & $\begin{array}{l}46 \\
44 \\
43\end{array}$ & $\begin{array}{l}44 \\
44 \\
42\end{array}$ & $\begin{array}{l}324 \\
275 \\
3.10\end{array}$ & $\begin{array}{l}15 \\
14 \\
17\end{array}$ \\
\hline Hampshire & 23 & $\begin{array}{l}\text { DH } \\
\text { DY } \\
\text { HY }\end{array}$ & $\begin{array}{l}43 \\
42 \\
43\end{array}$ & $\begin{array}{l}43 \\
42 \\
42\end{array}$ & $\begin{array}{l}260 \\
307 \\
247\end{array}$ & $\begin{array}{l}13 \\
13 \\
11\end{array}$ \\
\hline Yorkshire & 25 & $\begin{array}{l}\text { DH } \\
\text { DY } \\
\text { HY }\end{array}$ & $\begin{array}{l}48 \\
41 \\
42\end{array}$ & $\begin{array}{l}47 \\
41 \\
42\end{array}$ & $\begin{array}{l}321 \\
278 \\
267\end{array}$ & $\begin{array}{l}17 \\
15 \\
11\end{array}$ \\
\hline Total & 72 & & 392 & 387 & 2,589 & 126 \\
\hline
\end{tabular}
SIRES, LITTERS AND PIGS

${ }^{a_{D}}=$ Duroc, $H=$ Hampshire, $Y=$ Yorkshire. Breed of gilt includes reciprocal crosses (e.g., $D H$ includes both $D \times H$ and $H \times D$ females) in approximately equal numbers. 
where $y_{i j k l m}$ is the litter mean for the $i^{\text {th }}$ year-season, $j^{\text {th }}$ breed of sire, $k^{\text {th }}$ sire within season and breed of sire and $1^{\text {th }}$ breed of dam. $R_{k(i j)}$ and $e_{m(i j k l)}$ were assumed to be normally distributed independent random variables with zero mean and variance $\sigma_{r}^{2}$ and $\sigma_{e}^{2}$, respectively. All remaining factors were assumed to be fixed. Initial analysis showed that effects of sire within season-year and breed of sire were not significant for average number of pigs or litter weight at birth, 21 or 42 days. These traits were reanalyzed with sires excluded from the model. Fixed model analyses were accomplished with the Statistical Analysis System (Barr and Goodnight, 1972).

Survival percentage, average daily gain, days to $100 \mathrm{~kg}$, and average probe backfat and average pig weight at birth, 21 and 42 days were analyzed by mixed model procedures according to Harvey (1972). In these analyses, season, breed of sire and their interaction were tested by sire for statistical significance levels.

Feed efficiency and feed intake were analyzed with a fixed effects model including factors for season, breed of sire, breed of dam and two-and three -way interactions. Breed group pen means were the experimental unit for these analyses. Each pen contained both barrows and gilts, but this should not have affected the analyses since Bereskin et al. $(1975,1976)$ and Siers (1975) reported that barrows and gilts did not differ significantly in feed efficiency.

Least-squares means were computed for each breed group. Linear contrasts were performed to compare backcross to three-breed cross litters and to compare the average differences among breeds of sire and breeds of dam. More contrasts were made than there were available degrees of freedom, so the associated probabilities are not exact.

\section{Results and Discussion}

Reproductive Efficiencies. The distribution of reproductive successes and failures is shown in table 2. There were no significant differences between the reciprocal cross female groups; thus, they were combined. Differences between the breed groups in conception rate were very small, whether it was based on the number retained for breeding or the number that mated. The percentage of females that did not mate was $2.7 \%$; Johnson et al. (1978) reported nonmating rates of $8 \%$ among crossbreds and $10 \%$ among purebred females.

Litter Productivity. Breed group means and contrasts for litter productivity are shown in table 3. A contrast of particular interest is the comparison of three-breed cross litters with backcross litters, since this is an estimate of one-half individual pig heterosis (Dickerson, 1969). The difference for average number of pigs per litter was $.31 \pm .27, .57 \pm .24$ and $.50 \pm$ .24 pigs at birth, 21 , and 42 days, respectively. Three-breed cross litters were significantly heavier than backcross litters at 42 days, by 5.4 \pm 2.4 kilograms. The difference in average pig weight was small and nonsignificant at all ages. Survival rate of pigs from birth to weaning was higher among pigs in three-breed cross litters but not significantly so.

The heterosis estimates from this study are compared in table 4 with those reported by Young et al. (1976a) for purebreds and twobreed crosses of the same breeds. The estimates of one-half of the heterosis for litter size were 82,80 and $66 \%$ of the earlier estimates, and those for litter weight at 21 and 42 days were 62 and $57 \%$, as compared with an expected value of $50 \%$. The estimate of one-half heterosis for litter weight at birth was $20 \%$ greater than the previous estimate reported by Young $e t$ al.

TABLE 2. CONCEPTION RATES FOR CROSSBRED DAM GROUPS

\begin{tabular}{lllllll}
\hline Breed & $\begin{array}{l}\text { No. saved } \\
\text { for breeding }\end{array}$ & $\begin{array}{l}\text { No. } \\
\text { farrowing }\end{array}$ & $\begin{array}{l}\text { No. not } \\
\text { mating }\end{array}$ & $\begin{array}{l}\text { No. } \\
\text { open }\end{array}$ & $\begin{array}{l}\text { Conception rate } \\
\text { based on } \\
\text { gilts mated }\end{array}$ & $\begin{array}{l}\text { Concep tion rate } \\
\text { based on } \\
\text { gilts saved }\end{array}$ \\
\hline DH & 161 & 137 & 3 & 21 & 86.7 & 85.1 \\
DY & 144 & 127 & 3 & 14 & 90.1 & 88.2 \\
HY & 148 & 129 & 6 & 13 & 90.8 & 87.2 \\
Total & 453 & 393 & 12 & 48 & 89.1 & 86.8 \\
\hline
\end{tabular}

${ }^{a} \mathrm{D}=$ Duroc, $H=$ Hampshire, $Y=$ Yorkshire. Breed of gilt includes reciprocal crosses (e.g. DH includes both $\mathrm{D} \times \mathrm{H}$ and $\mathrm{H} \times \mathrm{D}$ females) in approximately equal numbers. 


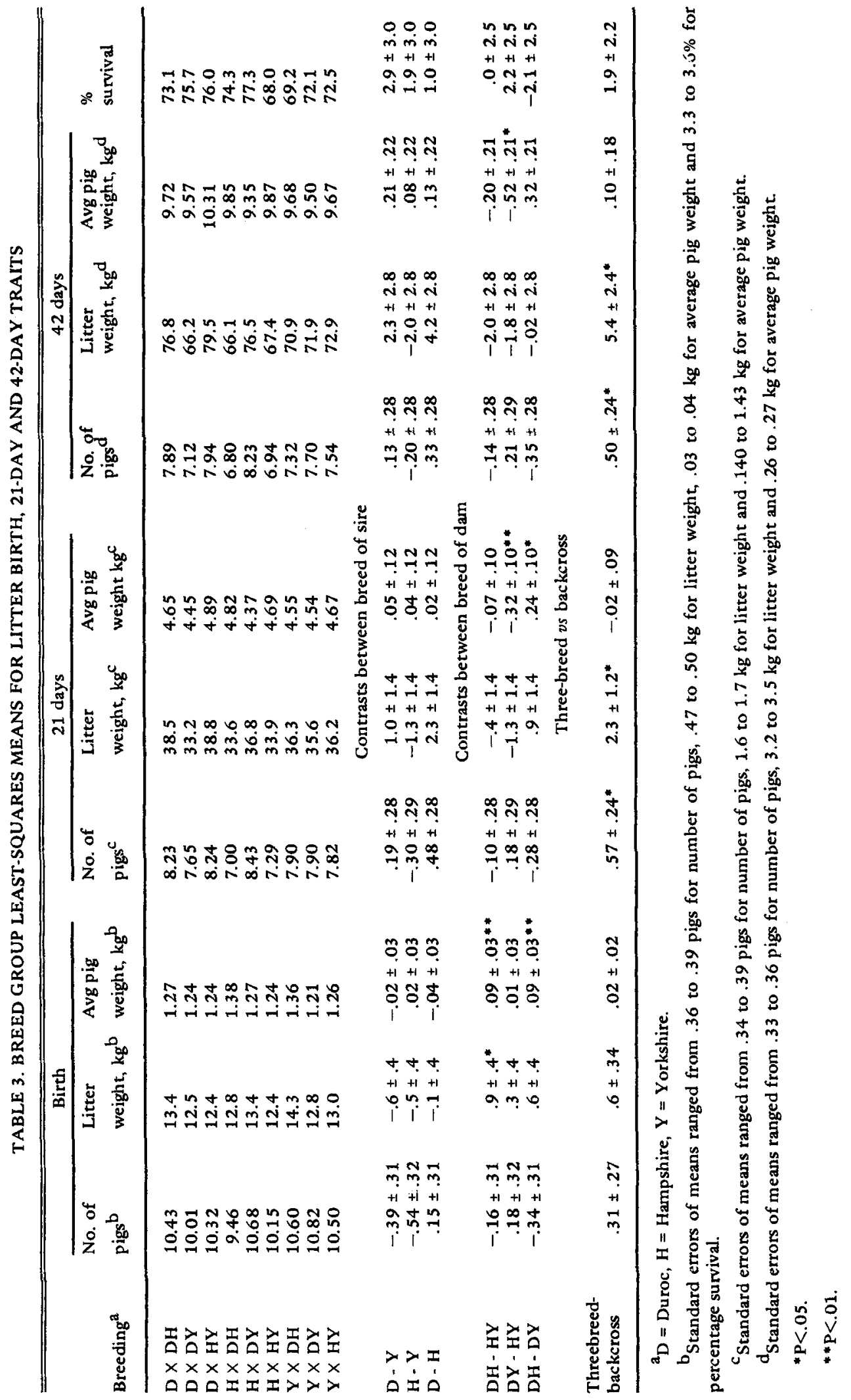




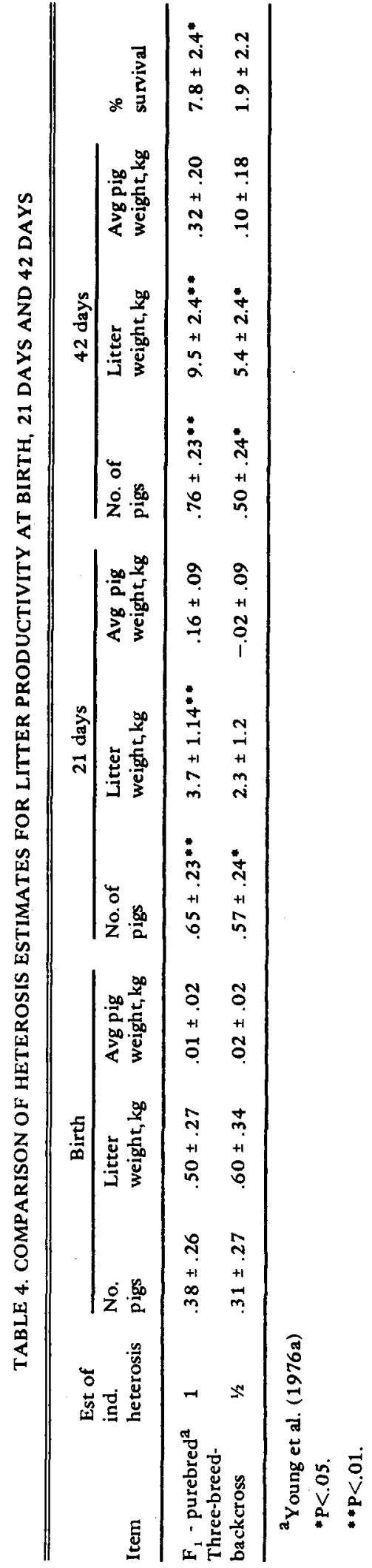

(1976a). The heterosis estimates in this study were also larger than those in the study by Schneider (1976), in which the difference between purebreds and crossbreds was .0 for number of pigs born and .29 for number of pigs at 56 days. Indications are that backcross matings do not have a greater-than-expected loss of individual heterosis for litter productivity. The estimate of heterosis for survival rate is lower than the earlier estimate.

Differences between Duroc-, Hampshire- and Yorkshire-sired litters in preweaning traits were small and nonsignificant. Yorkshire-sired litters tended to be larger at birth, but by 42 days Duroc-sired litters tended to be largest (table 3). Similar results were reported by Fahmy et al (1971) and Nelson and Robison (1976). Young et al. (1976a) found that Yorkshire-sired litters were significantly larger at 21 and 42 days than those sired by Duroc and Hampshire. Litter weight and average pig weight differences between sire breeds were small. Several other authors have found nonsignificant differences in average pig weight when these breeds have been used as sires (Fahmy et al., 1971; Nelson and Robison, 1976; Young et al., 1976a).

Although the contrasts between dam breeds were not significant for litter size at birth, 21 or 42 days, the differences were very consistent at all three ages (table 3). Holtmann et al. (1975) reported that Duroc-Yorkshire and HampshireYorkshire ranked sligh tly higher than HampshireDuroc, while Nelson and Robison (1976) reported the reverse ranking. Duroc-Hampshire dams produced litters that were $.9 \pm .4 \mathrm{~kg}$ heavier than those of Yorkshire-Hampshire dams at birth, but by 21 days this difference was not present. At birth Duroc-Hampshire females had the heaviest pigs $(P<.05)$, but by 21 days the average weight of their pigs was similar to that of pigs from Hampshire-Yorkshire dams. Pigs from Hampshire cross dams were heavier $(\mathrm{P}<.05)$ at 21 and 42 days than those from Duroc-Yorkshire females. At 42 days, pigs from Hampshire-Yorkshire dams were $.52 \pm .21$ $\mathrm{kg}$ heavier than those from Duroc-Yorkshire dams.

Since there were only small differences between sire breeds and crossbred dam types, it appears that a mating plan for litter production should involve the breed crosses that tend to be most productive as females, mated to maintain a high percentage of heterosis in the pigs.

Feedlot Performance. Table 5 presents the breed group means and contrasts for post- 
TABLE 5. BREED GROUP LEAST-SQUARES MEANS FOR POSTWEANING TRAITS

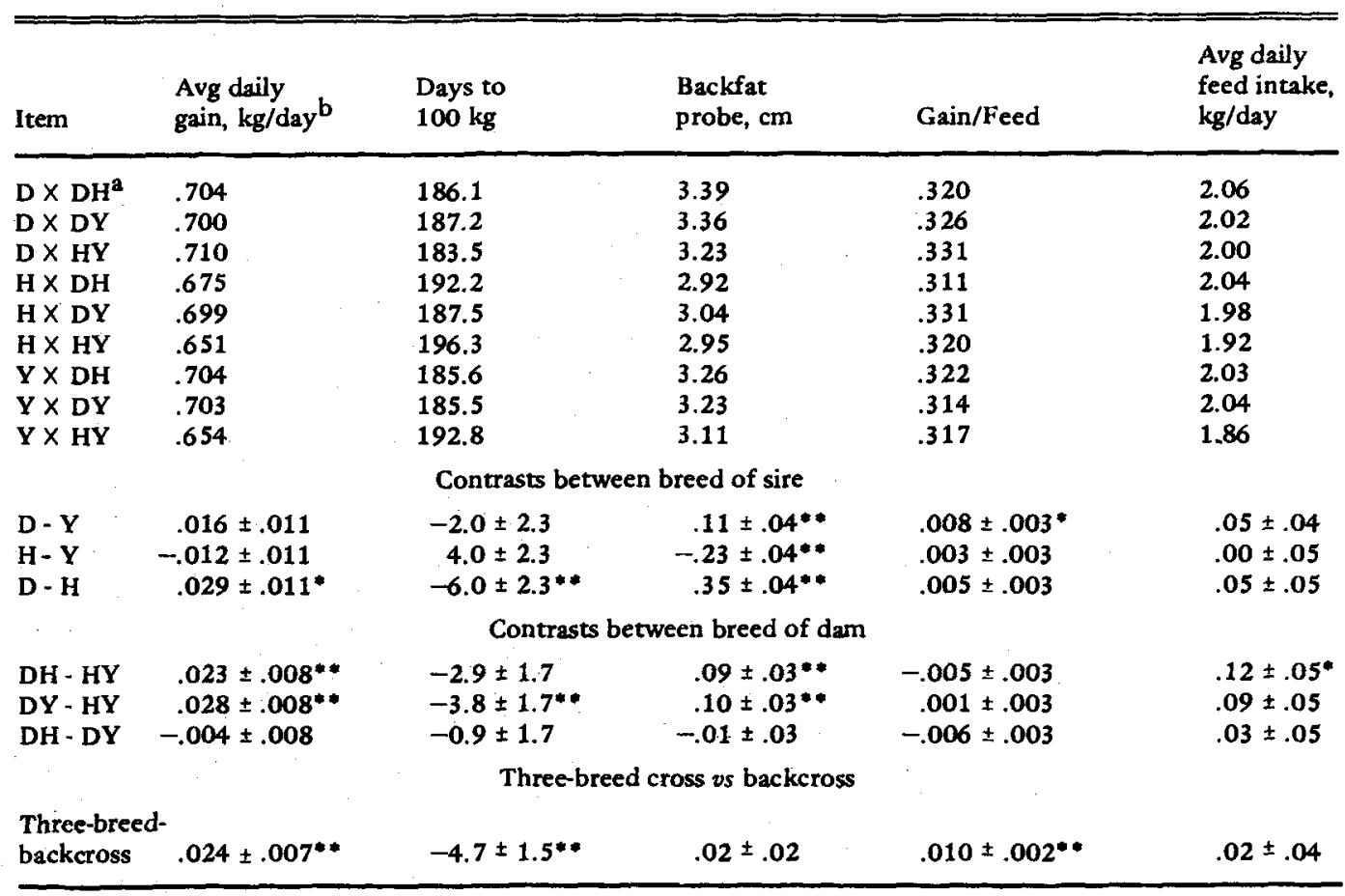

${ }^{a} \mathrm{D}=$ Duroc, $\mathrm{H}=$ Hampshire, $\mathrm{Y}=$ Yorkshire.

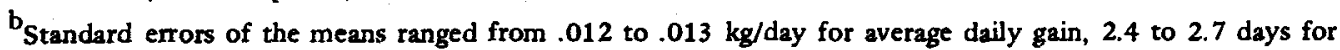
days to $100 \mathrm{~kg}, .04$ to $.05 \mathrm{~cm}$ for backfat probe, .003 to .004 for gain/feed and .05 to $.06 \mathrm{~kg} /$ day for average daily feed intake.

$* \mathrm{P}<.05$.

$\bullet \bullet<.01$.

weaning traits. Three-breed cross pigs grew significantly faster, were younger at $100 \mathrm{~kg}$ and were more efficient in feed utilization than backcross pigs. Young et al. (1976b) found significant individual heterosis for all of the postweaning traits that were measured in this study. The differences between three-breed cross pigs and backcross pigs in average daily gain and days to $100 \mathrm{~kg}$ were close to one-half the individual heterosis estimates given by Young et al. (1976b), which are shown in table 6.

Three-breed cross pigs had slightly more backfat probe than backcross pigs; however, this difference was not significant. Young et al. (1976b) reported less backfat probe (-.06 $\pm .03 \mathrm{~cm}$ ) for crossbred than purebred gilts, but slightly more $(.02 \pm .04 \mathrm{~cm})$ carcass backfat in crossbred barrows. Kuhlers et al. (1972) and Schneider (1976) also found little evidence of heterosis for carcass backfat. However, Bereskin et al. (1971) reported that crossbreds had .23 $\mathrm{cm}$ more carcass backfat thickness than purebreds. In general, it appears that heterosis for backfat must be close to zero.

The efficiency of feed utilization was significandy greater (3\%) among three-breed crosses than backcrosses. There was a nonsignificant difference in feed intake. Young $e t$ al. (1976b) reported an increase of $.0073 \pm$ $.0030 \mathrm{~kg}$ gain $/ \mathrm{kg}$ feed compared with an increase of $.010 \pm .002 \mathrm{~kg}$ gain $/ \mathrm{kg}$ feed in this study. This degree of heterosis is greater than most estimates reported in the literature. Kuhlers et al. (1972) did not find significant heterosis for feed conversion or feed intake for the period from 56 days to 90 kilograms. Young et al. (1976b) found that crossbred pigs consumed $.077 \pm .037 \mathrm{~kg}$ more feed per day than did purebred pigs. Except for findings on feed efficiency, the results from this experiment do not deviate greatly from theoretical expectations 
TABLE 6. COMPARISON OF HETEROSIS ESTIMATES FOR POSTWEANING TRAITS

\begin{tabular}{|c|c|c|c|c|c|c|}
\hline Item & $\begin{array}{l}\text { Est. of } \\
\text { ind. } \\
\text { heterosis }\end{array}$ & $\begin{array}{l}\text { Avg } \\
\text { gaily } \\
\text { gain, kg/day }\end{array}$ & $\begin{array}{l}\text { Age at } \\
100 \mathrm{~kg}\end{array}$ & $\begin{array}{l}\text { Backfat } \\
\text { probe, cm }\end{array}$ & Gain/feed & $\begin{array}{l}\text { Avg daily } \\
\text { feed intake } \\
\mathrm{kg} / \mathrm{day}\end{array}$ \\
\hline \multirow{2}{*}{$\begin{array}{l}\mathrm{F}_{1}-\text { purebred }^{2} \\
\text { Three-breed- } \\
\text { backcross }\end{array}$} & 1 & $.054 \pm .007^{* *}$ & $-9.9 \pm 1.3^{* *}$ & $-.06 \pm .03^{*}$ & $.007 \pm .003^{*}$ & $.08 \pm .04^{*}$ \\
\hline & $1 / 2$ & $.024 \pm .007^{*}$ & $-4.7 \pm 1.5 \cdots$ & $.02 \pm .02$ & $.010 \pm .002^{* *}$ & $.02 \pm .04$ \\
\hline
\end{tabular}

${ }^{a}$ Young et al. (1976b).

$-\mathrm{P}<.05$.

$\bullet P<.01$.

(50\% of previous estimates) in the amount of heterosis for postwe aning traits.

Duroc-sired pigs had higher average daily gains and were younger at $100 \mathrm{~kg}$ than Yorkshiresired pigs, and Yorkshire-sired pigs were $4.0 \pm$ 2.3 days younger at $100 \mathrm{~kg}$ than Hampshiresired pigs. This finding is in general agreement with previously published estimates. Nelson and Robison (1976) for example, reported that Duroc-sired pigs were heavier than Yorkshiresired pigs at 140 days of age, and that Yorkshiresired pigs were heavier than Hampshire-sired pigs when two-way cross pigs were produced. When three-breed cross pigs were produced, the differences between breeds of sire were very small. Fahmy et al. (1976) found that Yorkshire and Duroc-sired pigs were similar and that both were significantly younger than Hampshire-sired pigs at $90 \mathrm{~kg}$, while Young et al. (1976b) observed that Duroc-sired pigs were significantly younger at $100 \mathrm{~kg}$ than either Yorkshire- or Hampshire-sired pigs.

All contrasts between breeds of sire were significant for average backfat probe at $\mathbf{1 0 0}$ kilograms. Hampshire-sired pigs had .23 \pm $.04 \mathrm{~cm}$ less backfat than Yorkshire-sired pigs, and Yorkshire-sired pigs had $.11 \pm .04 \mathrm{~cm}$ less backfat than Duroc-sired pigs. This is in agreement with results reported by Young et al. (1976b) and Fahmy et al. (1976). Neison and Robison (1976) found that Yorkshire-sired pigs had a significantly greater backfat probe at $\mathbf{7 2 . 7}$ $\mathrm{kg}$ than did either Duroc- or Hampshire-sired pigs.

Duroc-sired pigs were the most efficient in feed utilization, significantly more so than Yorkshire-sired pigs. Differences in average daily feed consumption were small and nonsignificant.
Both Duroc-Hampshire and Duroc-Yorkshire females produced pigs that made greater average daily gains and were $2.9 \pm 1.7$ and $3.8 \pm$ 1.7 days younger at $100 \mathrm{~kg}$ than pigs from Hampshire-Yorkshire dams. Pigs from HampshireYorkshire dams were $.09 \pm .03$ and $.10 \pm .03$ $\mathrm{cm}$ leaner than those from Duroc-Hampshire and Duroc-Yorkshire dams. This result might be expected because of the general superiority of the Hampshire breed in backfat and the apparent maternal component for leanness in the Yorkshire (Young et al., 1976b). DurocYorkshire and Hampshire-Yorkshire females produced pigs that were similar in feed efficiency. Pigs with Duroc-Hampshire dams were least efficient. Offspring of Duroc-Hampshire females had significantly greater average daily feed consumption than pigs with HampshireYorkshire dams.

This experiment has shown that backcross pigs maintain heterosis values for litter traits and postweaning performance that are consistent with expected theoretical values. This information can be used to develop and evaluate crossbreeding systems to determine which are the most efficient for producing commercial market swine.

\section{Literature Cited}

Barr, A. J. and J. H. Goodnight. 1972. A User's Guide to the Statistical Analysis System. North Carolina State Univ., Raleigh.

Bereskin, B., R. J. Davey and W. H. Peters. 1976. Genetic, sex and diet effects on pig growth and feed use. J. Anim. Sci. 43:977.

Bereskin, B., R. J. Davey, W. H. Peters and H. O. Hetzer. 1975. Genetic and environmental effects and interactions in swine growth and feed utilization. J. Anim. Sci. 40: 53.

Bereskin, B., C. E. Shelby and L. N. Hazel. 1971. 
Carcass traits of purebred Durocs and Yorkshires and their crosses. J. Anim. Sci. 32:413.

Dickerson, G. E. 1969. Experimental approaches in utilizing breed resources. Anim. Breed. Abstr. 37:191.

Fahmy, M. H. and C. S. Bernard. 1971. Crossbreeding swine: Evaluation of twenty-eight crosses of market pigs. Can. J. Anim. Sci. 51:645.

Fahmy, M. H., C. S. Bernard and W. B. Holtman. 1971. Crossbreeding swine: Reproductive performance of seven breeds of sows bred to produce crossbred progeny. Can. J. Anim. Sci. 51:361.

Harvey, W. R. 1972. Program write-up for least-squares and maximum likelihood general purpose program. The Ohio State Univ., Columbus (Mimeo).

Holtmann, W. B., M. H. Fahmy, T. M. MacIntyre and J. E. Moxley. 1975. Evaluation of female reproductive performance of 28 one-way crosses produced from eight breeds of swine. Anim. Prod. 21:199.

Johnson, R. K., I. T. Omtvedt and L. E. Walters. 1973. Evaluation of purebreds and two-breed crosses in swine: Feedlot performance and carcass merit. J. Anim. Sci. 37:18.

Johnson, R. K., I. T. Omtvedt and L. E. Walters. 1978. Comparison of productivity and performance for two-breed and three-breed crosses in swine. $J$. Anim. Sci 46:69.

Kuhlers, D. L., A. B. Chapman and N. L. First. 1972.
Estimates of genotype-environment interactions in production and carcass traits in swine. $J$. Anim. Sci. 35:1.

Nelson, R. E. and O. W. Robison. 1976. Comparisons of specific two and three-way crosses of swine. J. Anim. Sci. 42:1150.

Schneider, James F. 1976. Heterosis combining ability and maternal ability estimated from single-crosses among four breeds of swine. M. S. Thesis. Iowa State Univ., Ames.

Sellier, P. 1976. The basis of crossbreeding in pigs; a review. Livestock Prod. Sci. 3: 203.

Siers, David G. 1975. Live and carcass traits in individually fed Yorkshire boars, barrows and gilts. J. Anim. Sci. 41:522.

Smith, H. G. and J. B. McLaren. 1967. Performance of breeds and breed crosses of swine. Tennessee Agr. Exp. Sta. Bull. 434.

Snedecor, George W. and William G. Cochran. 1967. Statistical Methods ( 6 th Ed.). The Iowa State University Press, Ames.

Young, L. D., R. K. Johnson and I. T. Omtvedt. 1976a. Reproductive performance of swine bred to produce purebred and two-breed cross litters. J. Anim. Sci. 42:1133.

Young, L. D., R. K. Johnson, I. T. Omtvedt and L. E. Walters, 1976b. Postweaning performance and carcass merit of purebred and two-breed cross pigs. J. Anim. Sci. 42:1124. 